\title{
Spatiotemporal variation of the bacterioplankton community in the German Bight: from estuarine to offshore regions
}

\author{
Judith Lucas*, Antje Wichels and Gunnar Gerdts
}

\begin{abstract}
Marine microbial biogeography has been studied intensively; however few studies address community variation across temporal and spatial scales simultaneously so far. Here we present a yearlong study investigating the dynamics of the free-living and particle-attached bacterioplankton community across a $100 \mathrm{~km}$ transect in the German Bight reaching from the Elbe estuary towards the open North Sea. Community composition was assessed using automated ribosomal intergenic spacer analysis and linked to environmental parameters applying multivariate statistical techniques. Results suggest that the spatial variation of the bacterioplankton community is defined by hydrographic current conditions, which separate the inner German Bight from the open North Sea and lead to pronounced differences in the coastal and offshore bacterioplankton community. However this spatial variation is overwhelmed by a strong temporal variation which is triggered by temperature as the main driving force throughout the whole transect. Variation in the free-living community was predominantly driven by temperature, whereas the particle-attached community exhibited stronger spatial variation patterns.
\end{abstract}

Keywords: North Sea, ARISA, Coastal ocean, Community composition, Environmental gradient

\section{Background}

Marine microbes are the most abundant organisms on earth [48], capable of thriving in all oceanic habitats and thus, constitute an enormous biodiversity. Due to their inexhaustible metabolic and physiological versatility they are substantial key players in every biogeochemical cycle and thus, are fundamental to ecosystem functioning. Hence, unveiling the mechanisms that regulate and maintain this diversity, microbial community assembly, distribution and variation is of fundamental interest in marine ecology. The existence of microbial biogeographic patterns is well established and it has been studied extensively in aquatic systems during the past few decades on various spatial scales $[11,22,23,28]$. A common understanding is that bacterial community similarity is decreasing with increasing geographic distance referred

\footnotetext{
*Correspondence: judith.lucas@awi.de

Alfred-Wegener-Institute Helmholtz-Center for Polar and Marine

Research, Biological Station Helgoland, Kurpromenade 201,

27498 Helgoland, Germany
}

to as "distance-decay" relationship. These spatial variations are often linked to dispersal limitation and shifts in physico-chemical environmental factors [15] that exhibit strong gradients. Among these environmental factors, temperature and salinity seem to have largest influence on global bacterial community structure and richness $[11,24]$. On the other hand microbial communities on microscales [23], within estuaries [46] and along transects of up to $2000 \mathrm{~km}[8,16]$ varied in response to organic matter distribution, salinity, temperature, depth, nutrient concentrations and suspended particles for instance. Furthermore, the temporal variation has been extensively studied in various aquatic environments. Seasonal shifts in bacterial community composition (BCC) are substantially driven by changes in temperature and nutrient concentrations [2, 13]. Multi-annual studies revealed that recurrence of bacterial community structure is predictable from ocean environmental conditions such as temperature and day length for instance $[10,14,27]$. However, marine habitats represent continuous, highly connected environments, where changes in 
bacterial communities are complex and triggered by temporal and spatial components simultaneously. So far, only few studies consider both components and describe spatiotemporal variation patterns in oceanic environments $[9,17,29]$.

The German Bight, located in the south-eastern part of the North Sea, is a relatively shallow $(10-40 \mathrm{~m})$ temperate, semi-enclosed continental shelf sea. Water currents in the German Bight are predominantly influenced by tides, wind forces and freshwater inflow from the rivers Elbe and Weser [19]. Mixing of marine and freshwater typically leads to pronounced salinity and temperature gradients. Additionally, high loads of dissolved and particulate organic matter are introduced from intertidal flats and Elbe and Weser rivers [25]. The environmental conditions in this highly dynamic ecosystem have been continuously monitored since 1962 around the Island of Helgoland in the German Bight $\left(54^{\circ} 11.3^{\prime} \mathrm{N}, 7^{\circ} 54.0^{\prime} \mathrm{E}\right)$, known as the Helgoland Roads time series [49]. The herein recorded data include physico-chemical parameters such as temperature, salinity, Secchi-depth, and concentrations of dissolved inorganic nutrients (phosphate, nitrate, nitrite, ammonium, silicate), as well as biological parameters such as qualitative and quantitative data on phyto-, zoo- and bacterioplankton.

The bacterioplankton community at Helgoland Roads has been in-deep studied under temporal aspects using a wide range of different microbiological and molecular methods. Seasonal variation was demonstrated on different time scales covering several months to multiple years using fingerprint methods like ribosomal intergenic spacer analysis (RISA), denaturing gradient gel electrophoresis (DGGE) and 16S rRNA gene tag sequencing $[12,27,36]$. The authors linked variation in community composition with various environmental parameters and revealed temperature and phytoplankton abundance as main driving forces. Short-term variation of the bacterioplankton community at Helgoland Roads during a spring phytoplankton bloom was analyzed in the frame of a comprehensive metagenomic and proteomic study [45]. Additionally, day to day variation was linked to variation in the molecular composition of dissolved organic matter (DOM) to investigate bacteria-DOM interactions [26]. Although temporal aspects have been well studied, spatial variation patterns in the German Bight have rarely been examined. One study by Rink et al. [33] compared bacterial communities at pelagic offshore and coastal inshore sites in the German Bight, in relation to suspended particulate matter and phytoplankton composition. However, conditions at Helgoland Roads are assumed to be influenced by the large-scale hydrographic regime in the German Bight [31, 43], thus, observed changes in the bacterial community are complex and comprise both temporal (succession) and spatial (dispersion) components. There is one example by Sperling et al. [41] who demonstrate how the currents in the German Bight may affect the occurrence of specific bacterial taxa. The authors linked the occurrence of the prominent lineages Roseobacter clade affiliated (RCA) cluster and SAR11 clade with the current patterns in the southern North Sea. A single study by Selje and Simon [39] observed spatiotemporal dynamics of the community composition in the salinity gradient along the Weser and the Weser estuary. Nonetheless, these studies only considered specific bacterial lineages or only nearshore sites and thus, knowledge on spatiotemporal variation of the whole community on gradients from coast to offshore in the German Bight does not exist.

In this study the spatiotemporal variation of bacterioplankton community in the German Bight was analyzed by automated ribosomal intergenic spacer analysis (ARISA) and multivariate statistical techniques. To integrate the temporally well studied community variation at Helgoland Roads into a spatial context within the German Bight, the surface water community was sampled on a monthly basis over a period of 1 year along two transects, from the Elbe estuary towards the open North Sea. We aimed at disentangling the temporal and spatial patterns in community variation and focused on the identification of relevant environmental parameters that drive these variation patterns. Furthermore we tried to uncover differences in the regulation of community assembly of the free-living and particle-attached bacteria.

\section{Methods}

Sampling and measurements of environmental parameters Water samples were obtained monthly at 15 stations along two transects on board the research vessel Uthörn from March 2012 to February 2013 (Fig. 1). The P8 transect starts at Helgoland Island, located in the inner German Bight (54 $\left.18.31 N, 7^{\circ} 88.97 \mathrm{E}\right)$, heads in a northwestern direction from Helgoland Island and covers approximately $46 \mathrm{~km}$. The second transect reaches from Helgoland Island to the Elbe estuary at the German coast and is referred to as Elbe transect. Taken together, both transects span a distance of approximately $100 \mathrm{~km}$. At all stations, surface water was collected at $1 \mathrm{~m}$ depth using $5 \mathrm{~L}$ Niskin bottles attached to a CTD (SST-CTD90, Sea \& Sun Technology, Germany). Temperature, salinity, dissolved oxygen (DO), Chlorophyll a (Chl $a$ ), turbidity and colored dissolved organic matter $(\mathrm{cDOM})$ were recorded simultaneously. For determination of dissolved organic carbon (DOC) concentrations, $20 \mathrm{ml}$ of each sample were filtered through $0.7 \mu \mathrm{m}$ glass fiber filters $(\mathrm{GF} / \mathrm{F}$ Whatman, UK) into precombusted glass vials $\left(400{ }^{\circ} \mathrm{C}, 5 \mathrm{~h}\right)$, acidified to $\mathrm{pH} 2$ ( $\mathrm{HCl} 32$ \% p.a., Carl Roth, Germany) 


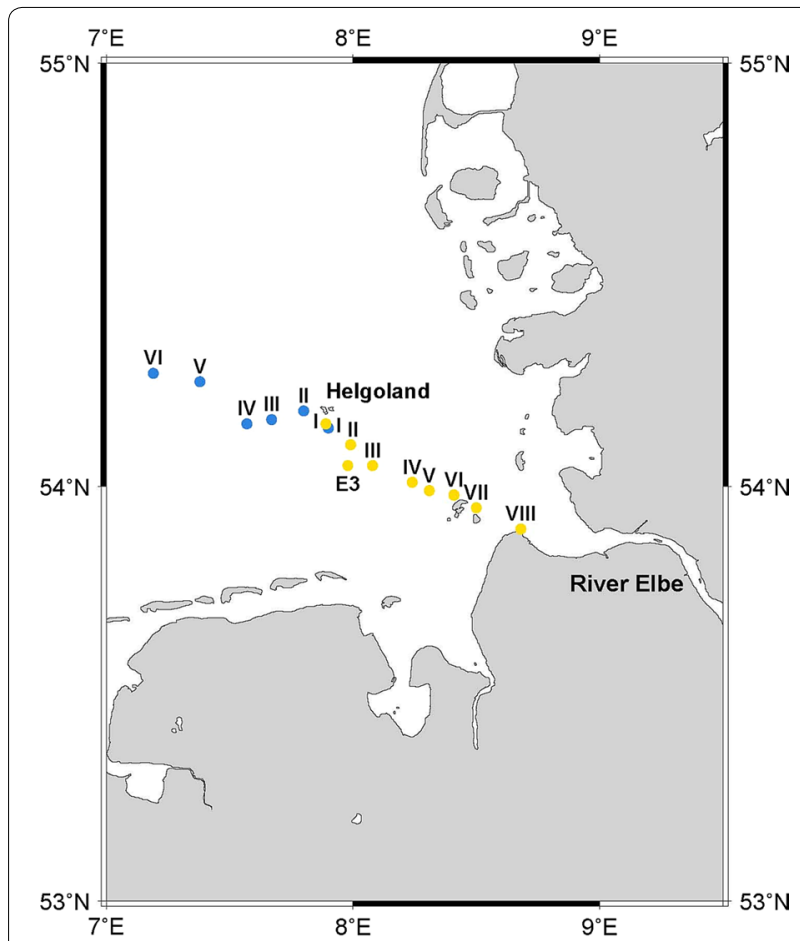

Fig. 1 Sampling sites along the two transects Elbe and $\mathrm{P} 8$ reaching from the Elbe estuary (German coastline) towards the open North Sea. Circles denote sampling sites along the transects Elbe (orange) and P8 (blue). Map was created with Ocean Data View (R. Schlitzer, http://odv.awi.de)

and stored at $4{ }^{\circ} \mathrm{C}$ in the dark. DOC concentrations were measured by high-temperature catalytic combustion using a TOC-VCPH/CPN total organic carbon analyzer (Shimadzu, Japan). The Deep Sea Reference Standard from the Consensus Reference Material Project (CRM; http://yyy.rsmas.miami.edu/groups/biogeochem/CRM. $\mathrm{html}$ ) was used to determine the precision and accuracy of the measured concentrations in each run.

\section{Bacterial community analysis}

$500 \mathrm{ml}$ of each sample were subjected to sequential filtration through 10, 3 and $0.2 \mu \mathrm{m}$ pore size polycarbonate filters (Millipore, Germany) to separate particle-attached from free-living bacteria. Filters with bacterial biomass were stored at $-20{ }^{\circ} \mathrm{C}$ until further processing. DNA extraction from the 3 and $0.2 \mu \mathrm{m}$ filters was done as described previously [36]. Briefly lysozyme and sodium dodecyl sulphate were used for cell lysis followed by extraction with phenol-chloroform-isoamylalcohol (25:24:1) and precipitation with isopropanol. DNA concentration per sample and purity were measured in duplicates using a Tecan Infinite M200 NanoQuant microplate reader (Tecan, Switzerland).
Automated ribosomal intergenic spacer analysis (ARISA) was performed as described in Krause et al. [21] with slight modifications. Extracted DNA was amplified with forward primer L-D-Bact-132-a-A-18 (5'-CCGGGTTTCCCCATTCGG-3') and reverse primer S-D-Bact-1522-b-S-20 (5'-TGCGGCTGGATCCCCTC$\left.C T T-3^{\prime}\right)$, the latter labelled with an infrared dye [32]. PCRs were performed in volumes of $25 \mu$ l containing $5 \mathrm{ng}$ template DNA. PCR products were diluted (1:5) with autoclaved ultrapure water. Diluted PCR products were then mixed with an equal volume of formamide containing loading buffer and $0.25 \mu \mathrm{l}$ were separated in $5.5 \%$ polyacrylamide gels at $1500 \mathrm{~V}$ for $14 \mathrm{~h}$ on a LI-COR 4300 DNA Analyzer. A 50-1500 bp size standard was run as a size reference on each gel (all materials: LI-COR Bioscience, USA).

Gels were analysed using the Bionumerics 5.10 software (Applied Maths, Belgium). Bands with intensities lower than $2 \%$ of the maximum value of the respective lane and bands smaller than 262 bp were neglected. Binning to band classes was performed according to Kovacs et al. [20]. Each band class is referred to as an ARISA operational taxonomic unit (OTU). Peak intensities of ARISA OTUs were translated to binary data reflecting the presence or absence of the respective OTU.

\section{Statistical analyses}

To reveal spatial and temporal patterns in environmental conditions along the sampled transects, principal component analysis (PCA) was accomplished for the environmental parameters. Parameters were normalized prior to analyses. To test for statistically significant variance among environmental parameters along the two transects, permutational multivariate analysis (PERMANOVA) was performed based on Euclidean distances at a significance level of $p<0.05$.

Accordingly, principal coordinates analyses (PCoA) were performed with the ARISA fingerprint data of the free-living and particle-attached bacterial communities separately, based on the Jaccard index. To test for statistically significant variance among the free-living and particle-attached bacterial communities and for differences among the community along the two transects respectively, PERMANOVA was accomplished at a significance level of $p<0.05$. Tests of significant differences in the within-group dispersion among groups were accomplished by performing tests of homogeneity of dispersions (PERMDISP) at a significance level of $p<0.05$. To identify axes separating the a priori groups (here P8 and Elbe transects), canonical analysis of principle coordinates (CAP) was performed. In contrast to unconstrained ordination techniques (e.g. PCA, PCoA) which maximize 
total variation among the samples, CAP tries to identify axes that separate samples into a priori defined groups in such a way that group differences are maximised [1]. Analyses were performed using Primer v.7 and the PERMANOVA add on software package (both PRIMER-E, UK). Spatiotemporal visualization of PCAs and PCoA scores was accomplished using Surfer 12 (GoldenSoftware, USA). Contour plots were created by using the point kriging method to generate the interpolated grid.

Spearman rank order correlations of environmental parameters were calculated at a significance level of $p<0.05$ to identify potential collinearity. To examine the relationship between the variation in the bacterial community and environmental parameters, stepwise forward multiple regression analyses (MRA) were conducted, using the PCoA scores of the first three PCoA axes as dependent variables and PCA scores of the first three PCA axes as independent variables referred to as principial component regression (e.g. [18]). Spearman rank order correlation and MRA were carried out using Statistica 11 (StatSoft, USA).

\section{Results}

\section{Spatiotemporal variation in environmental conditions}

For the recorded environmental parameters different variations across space and time were observed (Additional file 1: Figure S1). Salinity exhibited a pronounced spatial gradient along the two transects increasing from 15.8 (annual average) at the estuarine sampling site closest to the coastline (Elbe VIII) to 33.7 at the sampling site furthest offshore (P8 VI). Similar but reversed patterns were observed for DOC which decreased on average from $341.3 \mu \mathrm{M}$ in the estuary to $96.8 \mu \mathrm{M}$ offshore, turbidity (41.5-1.1 FTU), cDOM (26.6-2.5) and Chl $a$ (5.1 to $0.9 \mu \mathrm{g} \mathrm{l}^{-1}$ ). The slope of the observed gradient for the above mentioned parameters was relatively constant from sites P8 VI to Elbe V but became noticeably steep at the estuarine sites Elbe VI-Elbe VIII. In contrast, temperature was relatively stable along both transects, but varied temporally with lowest average values in February $\left(2.8{ }^{\circ} \mathrm{C}\right)$ and highest average values in September $\left(18.1^{\circ} \mathrm{C}\right)$. Dissolved oxygen exhibited a similar but reversed pattern as temperature and lowest average values were measured in September $\left(7.2 \mathrm{mg} \mathrm{l}^{-1}\right)$; highest average values were measured in February $\left(11.1 \mathrm{mg} \mathrm{l}^{-1}\right)$. Although temperature and dissolved oxygen varied slightly from estuarine to offshore sites, they are referred to as temporal parameters as the variation on temporal scale was more pronounced.

Opposed variation of salinity and DOC, turbidity, $\mathrm{cDOM}$ and $\mathrm{Chl} a$ and temperature and dissolved oxygen is also reflected in Spearman correlation coefficients (Table 1). Salinity showed significant, negative correlations with $\operatorname{DOC}(R=-0.97)$, turbidity $(R=-0.82)$, $\operatorname{cDOM}(R=-0.95)$ and Chl $a(R=-0.69)$. Temperature was significantly correlated with dissolved oxygen $(R=-0.92)$.

Principal component analyses of the environmental parameters revealed distinct patterns in sample variation (Fig. 2). The first axis (PC 1) explained $56.6 \%$ of the observed variability and is mainly defined by a combination of salinity, DOC, turbidity and $\mathrm{CDOM}$, contributing with roughly equally weighted coefficients to PC 1 (Fig. 2a). The second axis (PC 2) was predominantly defined by the large coefficients of temperature and $\mathrm{DO}$ and explained $30.1 \%$ of the observed variation (Fig. $2 \mathrm{~b}$ ). The third axis (PC 3) still explained $9.3 \%$ of the variation. Chl $a$ contributed with a remarkable high coefficient to this axis (Fig. 2c). In general variation was higher at sites along the Elbe transect compared to sites along the P8 transect as reflected in the larger range of PCoA scores covered by samples along the Elbe transect compared to the P8 transect (Fig. 2).

\section{Spatiotemporal variation of bacterial community composition and relevant driving forces}

The bacterial community showed high variation throughout the sampling period. Varying numbers of OTUs revealed changes in species richness in both the freeliving and the particle-attached community during the

Table 1 Spearman rank order correlations of environmental parameters

\begin{tabular}{lccccc}
\hline & Temperature & Salinity & DO & Chl $\boldsymbol{a}$ & Turbidity \\
\hline Salinity & -0.06 & & & & \\
DO & -0.92 & -0.14 & & & \\
Chla & 0.47 & -0.69 & -0.26 & & \\
Turbidity & -0.12 & -0.82 & 0.23 & 0.50 & 0.88 \\
CDOM & -0.14 & -0.95 & 0.33 & 0.54 & 0.81 \\
DOC & 0.14 & -0.97 & 0.04 & 0.71 & 0.92 \\
\hline
\end{tabular}

Significant correlations $(p<0.05)$ are indicated in italics

DO dissolved oxygen, $C h l a$ Chlorophyll a, $C D O M$ colored dissolved organic matter, $D O C$ dissolved organic carbon 

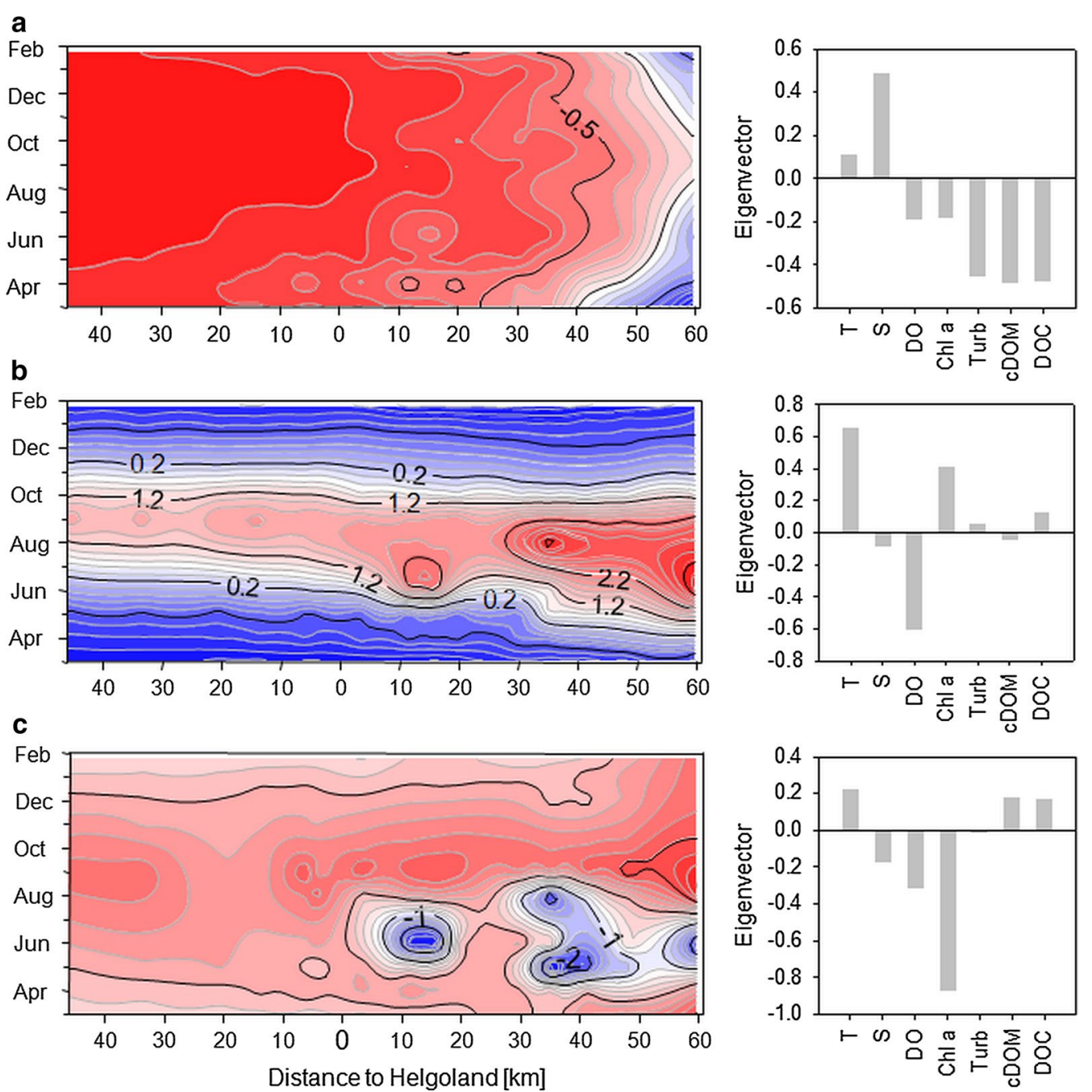

Fig. 2 Principal component analyses (PCA) of measured environmental parameters. PCA scores of the first PCA axis (a), second PCA axis (b) and third PCA axis (c) are depicted in contour plots. The horizontal axis depicts the distance $(\mathrm{km})$ of sampling sites to Helgoland Island which was set to $0 \mathrm{~km}$. Increasing distance to the left represents the sampling sites along the P8 transect, increasing distance to the right represents sampling sites along the Elbe transect. The vertical axis refers to the sampling date; color code reflects PCA scores of respective samples with blue colors indicating lower scores and red colors indicating higher scores. Coefficients of the environmental parameters in the linear combinations defining the respective PCA axes are given next to the contour plots. T temperature, S salinity, DO dissolved oxygen, Chl a Chlorophyll a, Turb turbidity, cDOM colored dissolved organic matter, DOC dissolved organic matter

course of the sampling campaign (Additional file 1: Figure S2). Concerning the bacterial community composition, PERMANOVA revealed significant $(p<0.05)$ differences between the free-living and particle-attached bacterial community (Additional file 1: Figure S3 and Table S1). To further elucidate patterns of variation within the free-living and particle-attached community, multivariate statistical analyses were accomplished separately for each fraction. To identify which environmental parameters are most likely to drive the variation, MRA were conducted with PCoA axes as dependent variables. To account for multicollinearity as revealed by high significant correlations $(|\mathrm{r}|>0.7)$ of environmental parameters (Table 1) and to avoid erroneous MRA we replaced the original environmental data by scores of the PCA axes as explanatory variables (also referred to as latent variables), according to the "Principial component regression" approach $[7,18]$. Since PCA axes are orthogonal (i.e. perfectly uncorrelated) multicollinearity was completely removed by this approach.

The free-living bacterial community exhibited a pronounced spatiotemporal pattern when taking the scores of the first PCoA axis into account (Fig. 3), explaining $15.1 \%$ of the total variation. The pattern of PCoA 1 

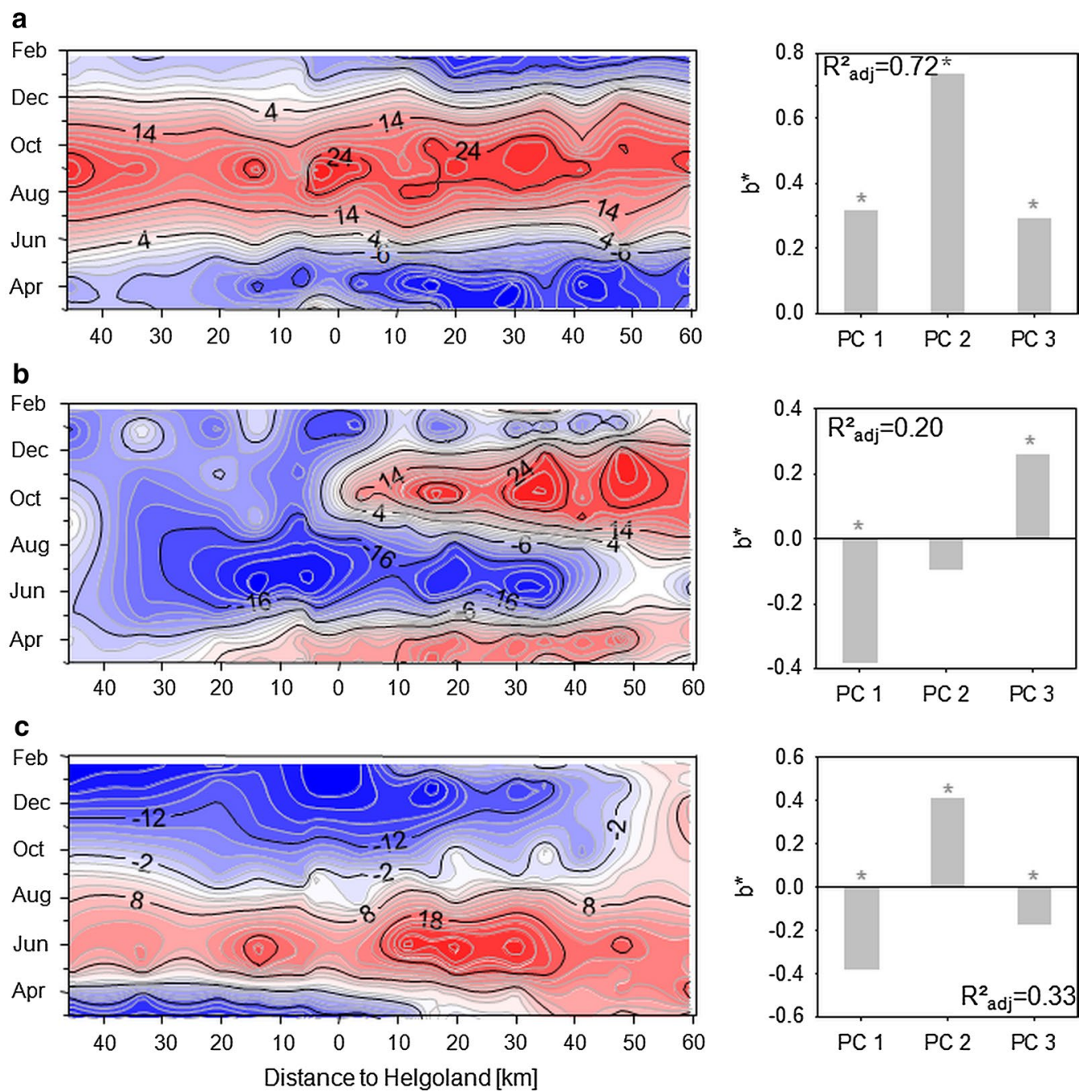

Fig. 3 Principal coordinates analysis (PCOA) of ARISA OTUs of the free-living fraction, based on Jaccard index. PCoA scores of the first PCoA axis (a), second PCOA axis $(\mathbf{b})$ and third PCoA axis (c) are depicted in contour plots. The horizontal axis depicts the distance $(\mathrm{km})$ of sampling sites to Helgoland Island which was set to $0 \mathrm{~km}$. Increasing distance to the left represents the sampling sites along the P8 transect, increasing distance to the right represents sampling sites along the Elbe transect. The vertical axis refers to the sampling date; color code reflects PCoA scores of respective samples with blue colors indicating lower scores and red colors indicating higher scores. Standardized regression coefficients (b*) of PCA axes of MRA using scores of PCoA axes as dependent and scores of PCA axis as independent variables are depicted next to the corresponding contour plots. MRA were done at a significance level of $p<0.05, R_{\text {adj }}^{2}$ values are given

scores in summer was clearly different from that in spring and winter along both transects (Fig. 3a). The spatiotemporal variation of PCoA 1 scores is significantly $(p<0.05)$ and well described $\left(\mathrm{R}_{\mathrm{adj}}^{2}=0.72\right)$ by the regression model. Among the explaining latent variables, PC 2 showed highest relative contribution to the prediction of PCoA 1 (Fig. 3a) as reflected in the high standardized regression coefficient $\left(b^{*}=0.73\right)$. PC 2 is mainly characterized by temperature as reflected in the high coefficient of temperature in the linear combination defining PC 2 (Fig. 2b). PC 1 and PC 3 contribute less $\left(b^{*}=0.32\right.$ and $b^{*}=0.29$, respectively), but still significantly to the prediction of the variation pattern of PCoA 1 . The second
PCoA axis (PCoA 2) explains $11.6 \%$ of the total variation (Fig. 3b). The PCoA 2 pattern of the P8 transect northwest off Helgoland was homogenous throughout the whole year, whereas pronounced variation was observed along the Elbe transect. Here, the pattern in late spring and summer (May to August) was similar to that of the P8 transect, but differed strongly from that in spring and autumn along the Elbe transect. The spatiotemporal pattern of PCoA 2 is significantly $(p<0.05)$ described by a combination of PC 1 (characterized by salinity, DOC, turbidity, cDOM) and PC 3 (mainly defined by Chl $a$ ) (Fig. 3b). Considering the low coefficient of determination $\left(R_{\text {adj }}^{2}=0.20\right)$, the variation of PCoA 2 scores is 
explained rather poorly. The third axis (PCoA 3) explains $9.1 \%$ of the total variation and demonstrates high similarity of the pattern along both transects during late spring and summer (May to July) (Fig. 3c). However, the pattern during spring and summer exhibited pronounced differences when compared to the patterns of autumn and winter. PC 1 and PC 2 contributed significantly with comparable amounts to the prediction of PCoA 3 ( $b^{*}=-0.38$ and $\left.b^{*}=0.41\right)$. PC 3 contributed to a less extend to the prediction $\left(b^{*}=-0.18\right)$ (Fig. 3c). As for PCoA 2, the MRA model for PCoA 3 exhibited a low coefficient of determination $\left(R_{\text {adj }}^{2}=0.3\right)$.
Figure 4 depicts the spatiotemporal variation of the respective PCoAs of the particle-attached bacterial community. PCoA 1 explains $16 \%$ of the total variation, PCoA 2 explains $10.4 \%$ and PCoA 3 explains $7.3 \%$ (Fig. 4). For PCoA 1 the spatiotemporal pattern of the entire P8 transect was homogenous throughout the year, whereas the pattern along the Elbe transect was clearly more variable (Fig. 4a). In late spring and summer (May to August) the pattern along the Elbe transect was similar to that of the P8 transect, but varied from the early spring, autumn and winter patterns along the Elbe transect. The variation pattern of PCoA 1 seems to be mainly
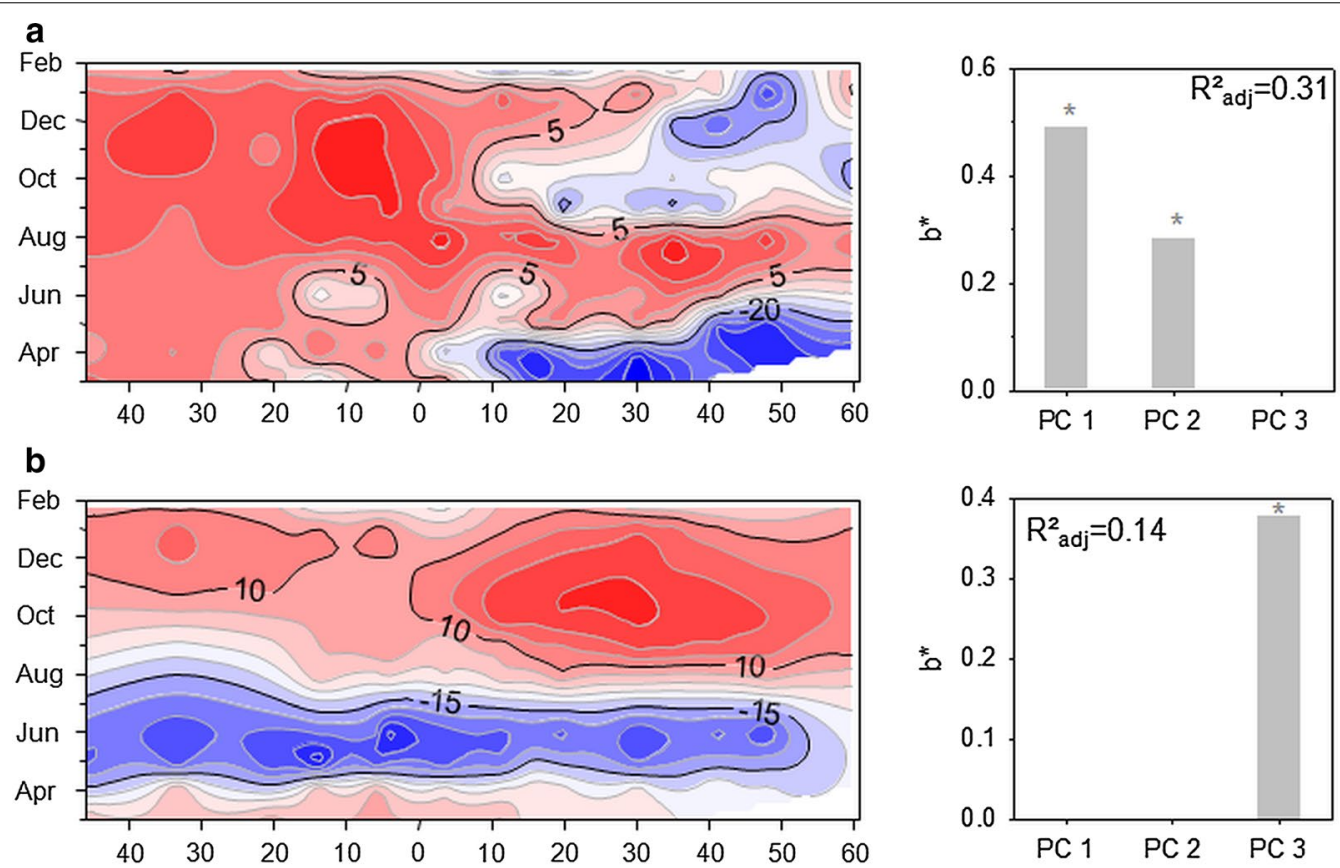

C
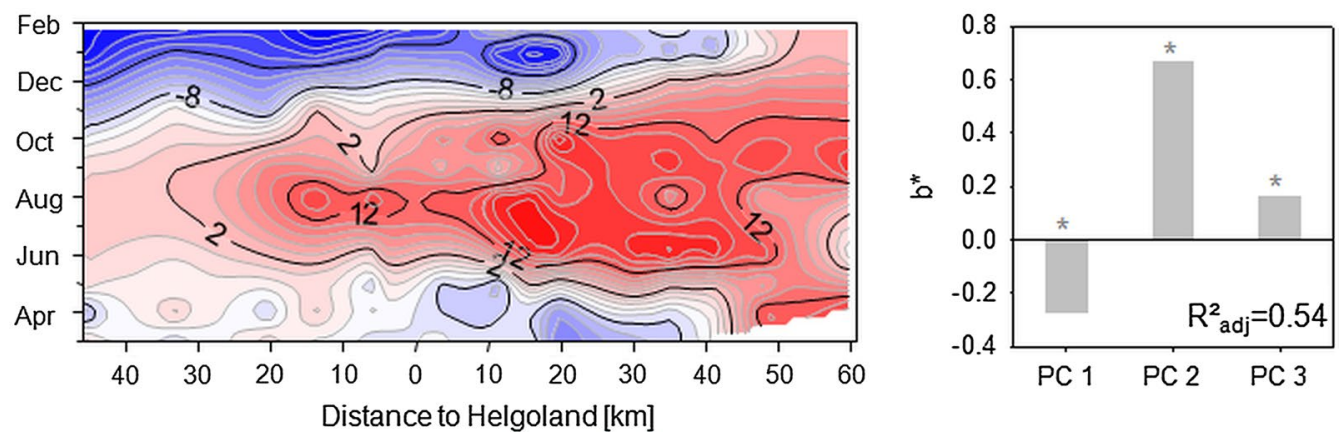

Fig. 4 Principal coordinates analysis (PCOA) of ARISA OTUs of the particle-attached fraction, based on Jaccard index. PCoA scores of the first PCoA axis $(\mathbf{a})$, second PCoA axis $(\mathbf{b})$ and third PCoA axis (c) are depicted in contour plots. The horizontal axis depicts the distance $(\mathrm{km})$ of sampling sites to Helgoland Island which was set to $0 \mathrm{~km}$. Increasing distance to the left represents sampling sites along the P8 transect, increasing distance to the right represents sampling sites along the Elbe transect. The vertical axis refers to the sampling date; color code reflects PCoA scores of respective samples with blue colors indicating lower scores and red colors indicating higher scores. Standardized regression coefficients ( $\left.b^{*}\right)$ of PCA axes of MRA using scores of PCOA axes as dependent and scores of PCA axis as independent variables are depicted next to the corresponding contour plots. MRA were done at a significance level of $p<0.05, R_{\text {adj }}^{2}$ values are given. Asterisks indicate significance of regression coefficient 
predicted by PC 1 (mainly defined by salinity, DOC, turbidity, cDOM) with $\mathrm{b}^{*}=0.49$ and to a less but still considerable amount by PC 2 (temperature) with $b^{*}=0.28$ (Fig. 4a). The variation pattern of PCoA 2 along time and space is depicted in Fig. 4b. Here, the pattern in spring (April to June) was similar along both transects, but clearly differed from the patterns in summer, autumn and winter. Variation of PCoA 2 is solely explained by PC 3 (mainly defined $\mathrm{Chl} a$ ), contributing with a standardized regression coefficient of $b^{*}=0.38$ to the prediction of PCoA 2 (Fig. 4b). Variation of PCoA 3 (Fig. 4c) reveals general differences between summer and winter. Focusing on the variation during summer (June to August), it becomes clear that the pattern along the Elbe transect and sites P8 I to III was particularly similar. Spatiotemporal patterns of PCoA 3 are significantly explained by PC 2 (defined by temperature) to a large extend $\left(b^{*}=0.67\right)$ (Fig. 4c). PC 1 and PC 3 also contributed significantly but to a much lower extend $\left(b^{*}=-0.27\right.$ and $\left.b^{*}=0.16\right)$ to the prediction of PCoA 3.

The variation patterns of the particle-attached bacterial community are generally less well described than the patterns in the free-living community, which is reflected in the low $R_{\text {adj }}^{2}$ values $\left(R_{\text {adj }}^{2}=0.31\right.$ for PCoA $1, R_{\text {adj }}^{2}=0.14$ for PCoA 2 and $R_{\text {adj }}^{2}=0.54$ for PCoA 3).

\section{Separation of samples into a priori groups corresponding to the sampled transects}

The variation patterns of the free-living and particleattached bacterial communities point to differences in community composition between the P8 transect and the Elbe transect (Figs. 3b, 4a) and thus, might suggest a separation of samples into the two a priori groups, corresponding to the two transects. Indeed, comparison of both transects via PERMANOVA revealed significant $(p<0.05)$ differences in community composition of the free-living and particle-attached bacterial community as well as differences in environmental parameters (Additional file 1: Table S1). However, PERMDISP also revealed significant differences in dispersion of the respective data sets (Additional file 1: Table S2). These evidenced heterogeneities in dispersion may affect PERMANOVA results adversely and thus, PERMANOVA results need to be interpreted with caution. Alternatively and as a complementary approach, canonical analysis of principal coordinates (CAP) was used to identify an axis separating the multivariate data cloud and possibly relocating samples allocated falsely to one of the a priori groups. Separation of samples along this axis helps to further characterize the a priori groups of samples, to visualize differences among them and to assess how distinct these groups are from each other. Separation of samples into the two a priori groups (P8 and Elbe) via CAP partly confirmed the significant differences that have been revealed by PERMANOVA (Fig. 5; Table 2). Concerning the free-living bacterial community the separation of the a priori groups (Fig. 5a) is supported by the reasonably large correlation value of 0.85 (Table 2), which indicates the strength of the association between the multivariate data and the hypothesis of group differences. However, $9.5 \%$ of the samples were misclassified, most of which derived mainly from sampling site Elbe I (Table 2) in the vicinity of the island of Helgoland. Accordingly, separation of a priori groups based on the particle-attached community composition (Fig. 5b), revealed a comparably high correlation value $(0.83)$ and a misclassification error of $10.7 \%$ (Table 2). The majority of the misclassified samples derived from sampling sites Elbe I and Elbe II. However, separation of samples based on environmental parameters (Fig. 5c) led to a considerably lower correlation value of 0.6 and a higher misclassification error of 18.9 \% (Table 2). Here, most of the misclassified samples belong to sampling sites Elbe I to Elbe III. Noticeably, in January and February samples from sites Elbe IV and V were also misclassified.

\section{Discussion}

Although temporal and spatial patterns of bacterial communities have been studied intensively in various marine environments only few studies consider the simultaneous variation in time and space $[9,17,29]$. Here we present a comprehensive spatiotemporal annual survey of the bacterioplankton community along a $100 \mathrm{~km}$ transect in the German Bight (North Sea) reaching from brackish waters (Elbe estuary) to offshore sites and link it with environmental parameters. This extensive analysis of the mechanisms that drive the spatiotemporal variation patterns in the German Bight adds to the knowledge that has been gained during a comprehensive annual survey on the bacterial community composition at Helgoland Roads using 16S rRNA gene tag sequencing [27]. In combination both studies draw a comprehensive, detailed picture of the variation patterns of the bacterial community in the German Bight.

\section{Helgoland roads: an oceanographic transition zone}

Principal component analysis revealed that the variation in environmental parameters was mainly driven by spatial gradients and to a less extend by temporal patterns. It is known that the coastal waters of the German Bight are strongly influenced by the discharge of Elbe riverine water, which represents the most relevant freshwater source in the German Bight [5]. This freshwater input is accompanied by high nutrient and particle loads and leads to the observed pronounced gradients of increasing salinity and decreasing concentrations of DOC, $\mathrm{CDOM}$, nutrients and 

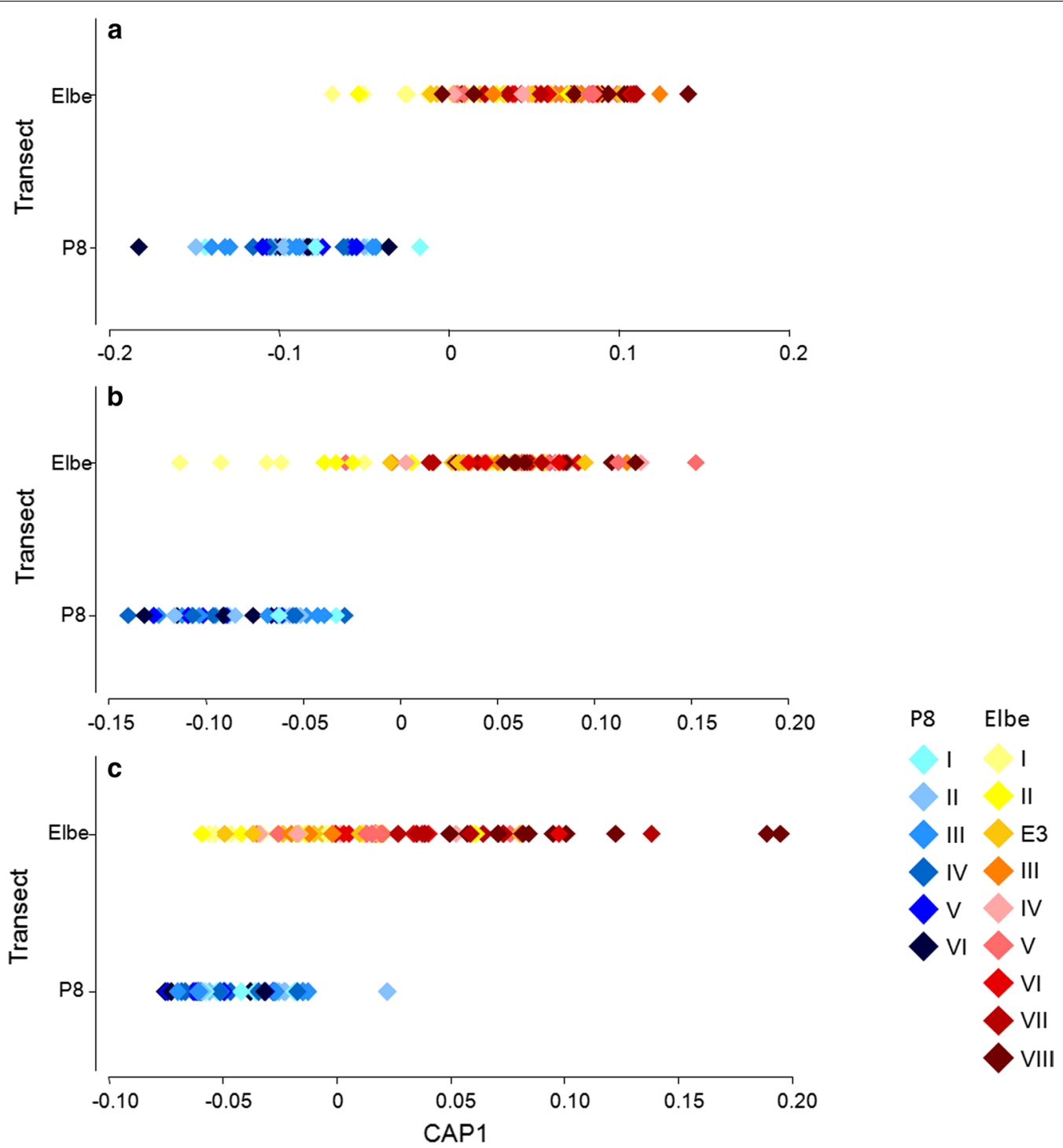

Fig. 5 Canonical analysis of principal coordinates (CAP). Separation of a priori groups (P8 and Elbe) based on (a) free-living bacterial community composition, (b) particle-attached bacterial community composition and (c) environmental parameters. Roman numerals in the legend refer to the corresponding sampling sites along the P8 and Elbe transects

turbidity from the Elbe estuary towards offshore areas. However, the observed gradient was most pronounced at the Elbe transect sites between Helgoland Island and the coastline; environmental conditions at the offshore sites (P8 transect) north-west off Helgoland appeared to be more homogenous which might be due to different influencing water masses. Scharfe [38] stated that the main water current pattern in the German Bight is characterized by advection of water masses from a western direction into the German Bight, which then moves on in a northern direction. Helgoland Island is located at the eastern boundary of this main current direction. Thus, it might be seen as border, where sampling sites north-west of Helgoland are influenced by water masses following this main current pattern and exhibit oceanic environmental conditions. In contrast, sampling sites south-east of Helgoland are influenced by costal water masses and river Elbe inflow, i.e. coastal conditions with high particle load and nutrient concentrations but low salinity predominate. However, the Helgoland area is occasionally influenced by riverine dominated coastal waters, controlled by hydrological and meteorological forces and river discharge [43], which might result in short-term interference of environmental conditions as demonstrated in Lucas et al. [26] and Teeling et al. [45]. Hence, the classification of water masses around Helgoland Island to 
Table 2 Canonical analyses of principal components (CAP) of the free-living and particle-attached bacterioplankton community and of environmental parameters (env)

\begin{tabular}{llll}
\hline & Free-living & Particle-attached & Env \\
\hline Eigenvalue & 1 & 1 & 1 \\
Correlation & 0.8456 & 0.8308 & 0.597 \\
Corr. sq. & 0.715 & 0.6902 & 0.3564 \\
Total correct & $115 / 127(90.6 \%)$ & $109 / 122(89.3 \%)$ & $103 / 127(81.1 \%)$ \\
Miss-classification error & $9.50 \%$ & $10.70 \%$ & $18.90 \%$ \\
\hline
\end{tabular}

Individual samples that were miss-classified

\begin{tabular}{|c|c|c|c|c|c|c|c|c|}
\hline \multicolumn{3}{|l|}{ Free-living } & \multicolumn{3}{|c|}{ Particle-attached } & \multicolumn{3}{|l|}{ Env } \\
\hline Sample & Orig. group & Class. group & Sample & Orig. group & Class. group & Sample & Orig. group & Class. group \\
\hline P8 I (Sep) & P8 & Elbe & P8 IV (Apr) & P8 & Elbe & P8 II (Apr) & P8 & Elbe \\
\hline Elbe I (Mar) & Elbe & P8 & P8 III (Jun) & P8 & Elbe & Elbe I (Mar) & Elbe & P8 \\
\hline Elbe I (Apr) & Elbe & P8 & P8 III (Mar) & P8 & Elbe & Elbe II (Mar) & Elbe & P8 \\
\hline Elbe I (May) & Elbe & P8 & Elbe I (May) & Elbe & P8 & Elbe I (May) & Elbe & P8 \\
\hline Elbe II (Jun) & Elbe & P8 & Elbe I (Aug) & Elbe & P8 & Elbe II (May) & Elbe & P8 \\
\hline Elbe I (Aug) & Elbe & P8 & Elbe V (Aug) & Elbe & P8 & Elbe III (May) & Elbe & P8 \\
\hline Elbe I (Oct) & Elbe & P8 & Elbe II (Jan) & Elbe & P8 & Elbe E3 (Aug) & Elbe & P8 \\
\hline Elbe I (Jan) & Elbe & P8 & Elbe III (Jan) & Elbe & P8 & Elbe I (Sep) & Elbe & P8 \\
\hline Elbe I (Feb) & Elbe & P8 & Elbe I (Feb) & Elbe & P8 & Elbe I (Oct) & Elbe & P8 \\
\hline Elbe E3 (Sep) & Elbe & P8 & Elbe I (Mar) & Elbe & P8 & Elbe $\|(O c t)$ & Elbe & P8 \\
\hline Elbe II (Jan) & Elbe & P8 & Elbe II (Mar) & Elbe & P8 & Elbe E3 (Oct) & Elbe & P8 \\
\hline \multirow[t]{13}{*}{ Elbe VIII (Mar) } & Elbe & P8 & Elbe I (Sep) & Elbe & P8 & Elbe III (Oct) & Elbe & P8 \\
\hline & & & Elbe II (Sep) & Elbe & P8 & Elbe I (Jan) & Elbe & P8 \\
\hline & & & & & & Elbe E3 (Jan) & Elbe & P8 \\
\hline & & & & & & Elbe III (Jan) & Elbe & P8 \\
\hline & & & & & & Elbe IV (Jan) & Elbe & P8 \\
\hline & & & & & & Elbe V (Jan) & Elbe & P8 \\
\hline & & & & & & Elbe I (Feb) & Elbe & P8 \\
\hline & & & & & & Elbe III (Mar) & Elbe & P8 \\
\hline & & & & & & Elbe E3 (Mar) & Elbe & P8 \\
\hline & & & & & & Elbe II (Sep) & Elbe & P8 \\
\hline & & & & & & Elbe E3 (Sep) & Elbe & P8 \\
\hline & & & & & & Elbe II (Jan) & Elbe & P8 \\
\hline & & & & & & Elbe IV (Feb) & Elbe & P8 \\
\hline
\end{tabular}

Orig. group the a priori group of the respective samples, Class. group the group classification resulting from CAP analyses

either marine or coastal water is not trivial and thus, the Helgoland area might be referred to as an oceanic transition zone between coastal and central North Sea waters as already suggested by Raabe and Wiltshire [31]. Canonical analyses of principal components of either environmental parameters or bacterial community composition strongly confirm this idea and further localize this transition zone more precisely as discussed in the following paragraph (Fig. 5). Along the investigated transects a strong gradient in spatial parameters as reflected by salinity, DOC, turbidity and $\mathrm{CDOM}$ from the Elbe estuary towards the central North Sea is obvious (Fig. 5c). This gradient is not consistent, but exhibits varying strength in different sections of the transects. It is most pronounced at the estuarine sites Elbe VI-VIII, where environmental conditions show strong, abrupt changes, reflected in the relatively large range in which samples of these sites stretch along the CAP axis (Fig. 5c). Towards Helgoland Island (Elbe IV and $\mathrm{V})$ environmental conditions are changing more gradually and thus, the gradient flattens. Approximately $20 \mathrm{~km}$ south-east of Helgoland Island environmental conditions become similar to that of the offshore sampling sites north-west of Helgoland (P8 transect) which is reflected in misclassification of samples of sites Elbe I-III (Table 2) and the visible overlap of sites Elbe I-III with sites of the P8 transect (Fig. 5c). 
However, the separation of samples based on environmental parameters was not congruent with CAP analysis of the bacterial community (Fig. 5a, b). The classification of samples suggested for the bacterial community lets us assume that a reasonable spatial separation of samples could be achieved by assigning all samples along the P8 transect plus the samples from sampling site Elbe I for the free-living community and samples along P8 plus sites Elbe I and II for the particle-attached community, into one group (referred to as offshore), and the remaining samples along the Elbe transect into a second group (coastal). A possible explanation is that different water masses with differing salinity and related density gradients might lead to dispersal limitation of bacterial populations, which might explain the observed separation of coastal (Elbe transect) and offshore (P8 transect) samples based on the free-living bacterial community composition. A comparable separation of water masses and thereby communities has been also proposed for other coastal-offshore transects [8], for deep-water research moorings [29] and on a global scale [11].

\section{Free-living and particle-attached bacterial communities are triggered differently}

Pronounced spatial patterns of marine bacterial community composition have been described for estuarine areas that exhibit strong salinity gradients $[8,46]$ as well as oceanic water masses with distinct gradients in salinity or temperature for instance $[11,16]$. However, as part of a semi-enclosed continental shelf sea the German Bight represents a unique, highly productive coastal environment that is strongly influenced by its intertidal flats, freshwater inflow of rivers and exhibits rather smallscale, highly variable hydrographic properties [3, 42]. Few studies systematically compared water or sediment bacterial community composition of coastal and oceanic sites in this region $[33,44]$ hence, knowledge of the spatiotemporal variation of the bacterial community and its driving forces in the German Bight is scarce.

Due to the above mentioned strong freshwater input of the Elbe River and the observed gradients in salinity, DOC, cDOM and turbidity, it could be assumed that the variation of the bacterial community composition changes gradually as well from riverine to marine habitats as shown by other studies on the spatial variability along environmental gradients [9, 16]. Surprisingly, variation in the free-living bacterial community was dominated by temporal changes in temperature along both transects, rather than by parameters that exhibit pronounced spatial gradients (salinity, DOC, turbidity, cDOM). Fuhrman et al. [11] defined temperature as the major influencing factor in a global large-scale study on bacterioplankton richness. They stated that temperature strongly affects kinetic mechanisms (rates of reproduction, dispersal, species interaction, adaptive evolution etc.) and thus, has potentially strong influence on the diversity. This is also supported by a recent study on the annual bacterial dynamics at Helgoland Roads [27]. The authors suggest that temperature constitutes a major factor for the formation of ecological niches in the German Bight and indirectly affects short-term bacterial succession in response to phytoplankton blooms. This supports the assumption that the variation of the bacterial community along the examined transect in the German Bight is mainly driven by temperature. The strong influence of temperature overlying other environmental factors like salinity, DOC, DOM (as represented by cDOM) and phytoplankton (as represented by $\mathrm{Chl}$ a) might also point to a relatively broad tolerance of the free-living coastal bacterial community concerning the latter factors. However, it has to be noted that this study is based on binary data, i.e. our diversity analyses only consider the presence or absence of ARISA OTUs. Relative abundances or activity of specific OTUs however, might be triggered by different environmental parameters depending on their respective ecological niches.

Considering the influences of the different environmental parameters, the impact of phytoplankton abundance (represented by Chl a concentrations) on the spatiotemporal free-living community variation in this study is particularly interesting. It is a known fact that bacterioplankton community composition is strongly influenced by enhanced substrate supply during and on decline of phytoplankton blooms and many studies assessed the response of bacterial communities to phytoplankton blooms with regard to different aspects [30, $34,35,37,45,47,50]$. Although our data also imply an influence of phytoplankton on the community structure, this influence is only of minor importance since the main contribution of Chl $a$ is to the third PCA axis (Fig. 2), which again is of minor importance for the explanation of the variation pattern of the free-living community (Fig. 3). There is a major contribution of Chl $a$ to the explanation of the variation pattern of PCoA 2 of the particle-attached community (Fig. 4b), but as the variation pattern is explained rather poorly $\left(R_{\text {adj }}^{2}=0.14\right)$ this does not point to a pronounced influence of phytoplankton on the community variation. Therefore, we propose that a strong influence of phytoplankton on the bacterioplankton community composition is restricted to short time scales during phytoplankton blooms and is of minor importance for the overall long-term patterns in community composition such as resilience and recurrence. This assumption is supported by an 16S rRNA gene tag sequencing based annual survey on the bacterioplankton community at Helgoland Roads that reported a rapidly 
changing community composition during phytoplankton blooms which was overwhelmed by temperature-driven seasonal variation [27]. However, interdependencies between phyto- and bacterioplankton cannot easily be disentangled since growth of both organism groups rely to some extent on the same environmental triggers (temperature, nutrients) and also interact (via exudates) or compete (nutrients) [4].

Despite the strong temporal influence, spatial patterns were also observed for the free-living community which is reflected in the patterns of PCoA 2 (Fig. 3b) albeit this patterns were merely explained by the measured environmental parameters $\left(R_{\text {adj }}^{2}=0.20\right)$. Due to this poor relationship of environmental parameters and patterns of PCoA 2, we assume that other factors that were not analyzed during this study might be relevant for interpretation. As already mentioned a varying coastal water inflow to the Helgoland area is assumed which is related to meteorological and hydrodynamic conditions and might result in short-term interference of environmental conditions $[38,43]$. To relate this varying current pattern in the coastal area with the observed PCoA 2 pattern the hydrodynamic variability in the German Bight was assessed using current velocity fields from the model BSHcmod [6] operated by the Federal Maritime and Hydrographic Agency of Germany (Bundesamt für Seeschiffahrt und Hydrographie, BSH) (detailed information see supplementary material; Additional file 1: Figures S3, S4). Deviations of the main current patterns in the German Bight within the period March 2012-March 2013 are depicted in Fig. 6a, b. It is obvious that hydrographic conditions at Helgoland Roads are influenced by current anomalies that represent an inflow of open North Sea waters (Fig. 6b). The corresponding time coefficient $\left(\mathrm{PC}_{\mathrm{Hyd}} 2\right)$ of this pattern is compared to the PCoA 2 pattern in Fig. 6c. Positive values of the time coefficient reflect the pattern depicted in Fig. 6b, negative values reflect the reverse pattern when central North Sea water flows into a northern

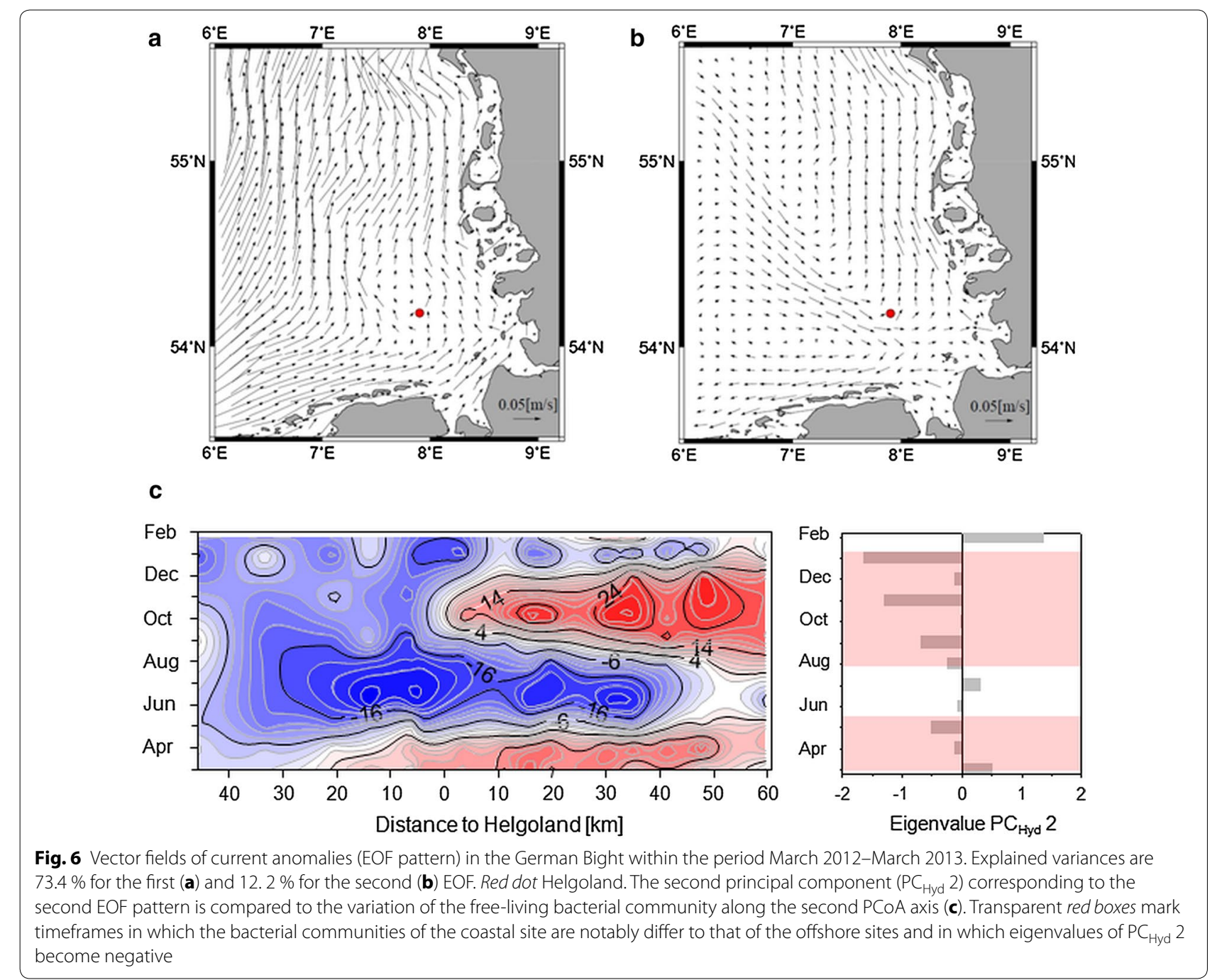


direction off Helgoland and is replaced by an inflow of coastal water. Since negative values of $\mathrm{PC}_{\mathrm{Hyd}} 2$ which are related to enhanced coastal water influence at Helgoland Roads occurred predominantly in spring and autumn, we assume that the observed differences of bacterial communities along the transect can be partly explained by these current patterns.

In contrast to the free-living community, the variation of the particle-attached community was mainly driven by salinity, DOC, cDOM and turbidity, thus following their pronounced spatial patterns (Fig. 4). Temperature dependent variation was not as relevant as for the freeliving community, which is evident from the relatively small contribution of PC 2 to the variation of the PCoAs (Fig. 4). However, spatiotemporal patterns of the particle-attached community were poorly explained by MRA analyses, reflected by the small $R_{\text {adj }}^{2}$ values. Thus, interpretation of the variation is difficult and the main driving forces remain unclear.

Although we demonstrated clear patterns in the variability of the bacterial community composition of the freeliving community in the German Bight, there are some drawbacks that need to be considered. First, the set of measured environmental variables was rather small and additionally composed of many parameters that exhibited a pronounced multicollinearity. Consideration of additional abiotic and biotic parameters describing top down or bottom up processes in more detail (nutrient availability, predation by grazers and lysis by viruses) might contribute to a better and more detailed explanation of the observed patterns. Second, microbial biogeography is not only driven by deterministic processes such as selection (i.e. adaptation to prevailing environmental conditions) but also by stochastic processes like dispersal and mutation as reported by Hanson et al. [15]. The authors argue that mutation might add noticeably to the compositional variability among different locations in particular, when considering highly variable genetic regions such as the intergenic spacer (IGS) region. However, to our knowledge there are no studies that focus on the effect of mutation on the variation of microbial biogeography. Third ARISA only captures the most dominant species [40], therefore missing a huge amount of diversity. Since the relationship between environmental factors and rare or dominant taxa might be different also according to their lifestyle (generalists vs. specialists), inferences on bacterial community variation based on ARISA fingerprints are limited.

Despite these drawbacks we were able to reveal clear patterns in the spatiotemporal community variation in the German Bight and to unravel possible driving mechanisms. To our knowledge this study is the first systematic investigation of the bacterioplankton community in the German Bight combining both, relatively fine spatial resolution and longterm scales. The results provide relevant new insights into the different driving mechanisms of the variation of the free-living and particle-attached bacterial community composition. We conclude that spatial variation within the German Bight is defined by pronounced hydrographic current conditions that separate the inner German Bight from the central North Sea and thus, may lead to dispersal limitation of the bacterioplankton community and distinct offshore and coastal populations. However, temporal influences are dominating over the spatial variation and seem to play a major role in community assembly. Temporal variation is triggered by temperature as the main driving force throughout the examined transect, and by underlying short-term events like phytoplankton blooms.

\section{Additional file}

Additional file 1: Table S1. Permutational analysis of variance (PERMANOVA). PERMANOVA main test of bacterial community composition was based on Jaccard dissimilarities of ARISA profiles. Main test of environmental parameters was based on Euclidean distances. P-values were obtained using type III sums of squares and 9999 permutations under the full model. df: degrees of freedom, SS: sums of squares, perms: number of unique permutations. All tests were done on a significance level of $p<0.05$; significant values are indicated in bold. Table S2. Tests of homogeneity of dispersion (PERMDISP). PERMDISP was performed on the basis of Jaccard dissimilarities of ARISA profiles for the bacterial community and on the basis of Euclidean distances for environmental parameters. P-values were obtained using 9999 permutations and tests were performed on a significance level of $p<0.05$; significant values are indicated in bold. N: Number of samples, Average: average distance to the group centroid on the scale of the chosen resemblance measure, SE: standard error for the distance to the group centroid. Figure S1. Contour plots of all measured environmental parameters. The horizontal axes depicts the distance [km] of sampling sites to Helgoland Island which was set to $0 \mathrm{~km}$. Increasing distance to the left represents offshore sampling sites, increasing distance to the right represents coastal sampling sites. The vertical axis refers to the sampling date; color code reflects measured values with of respective environmental parameters with yellow colours indicating lower values and red colors indicating higher values. A: salinity, B: dissolved organic carbon, C: turbidity, D: colored dissolved organic matter, E: temperature, F: dissolved oxygen, G: Chlorophyll $a$. Figure S2. Species richness, given as number of ARISA OTUS, at different sampling sites during the course of the sampling period. Colour code refers to species richness with low values reflected in white and high values reflected in red. (A) species richness of the free-living bacterial community. (B) Species richness of the particle- attached bacterial community. N.A.: not available. Figure S3. Principal coordinates analysis (PCOA) of ARISA OTUs of the free-living and particle attached fraction based on Jaccard index. Green triangles depict free-living fraction, blue triangles indicate particle-attached fraction. Figure S4. Vector fields of current anomalies (EOF pattern) in the German Bight within the period March 2012-March 2013. Explained variances are $73.4 \%$ for the first (A) and $12.2 \%$ for the second (B) EOF. Red dots: Helgoland. Figure S5. Principal components (PCs) corresponding to the EOF pattern shown in Figure S2.

Authors' contributions

GG, AW and JL conceived the study; JL performed sampling and all the analyses and data handling. All authors contributed to data interpretation. JL wrote 
the manuscript with significant input of all coauthors. All authors read and approved the final manuscript.

\section{Acknowledgements}

We would like to thank the crew of the Uthörn, Kristine Carstens and Silvia Peters and Matthias Friebe for technical assistance and help during sampling and DOC measurements. We gratefully acknowledge the provision of $\mathrm{BSH}$ cmod current velocity fields by the Federal Maritime and Hydrographic Agency of Germany (Bundesamt für Seeschifffahrt und Hydrographie, BSH, Hamburg) and the calculation of principal coordinates of water currents by Mirco Scharfe.

\section{Competing interests}

The authors declare that they have no competing interests.

Received: 25 November 2015 Accepted: 8 March 2016

Published online: 10 June 2016

\section{References}

1. Anderson MJ, Willis TJ. Canonical analysis of principal coordinates: a useful method of constrained ordination for ecology. Ecology. 2003;84:51125. doi:10.1890/0012-9658(2003)084[0511:CAOPCA]2.0.CO;2.

2. Andersson AF, Riemann L, Bertilsson S. Pyrosequencing reveals contrasting seasonal dynamics of taxa within Baltic Sea bacterioplankton communities. ISME J 2009;4:171-81. doi:http://www.nature.com/ismej/ journal/v4/n2/suppinfo/ismej2009108s1.html.

3. Becker G, Dick S, Dippner J. Hydrography of the German Bight. Mar Ecol Prog Ser. 1992;91:9-18.

4. Buchan A, LeCleir GR, Gulvik CA, González JM. Master recyclers: features and functions of bacteria associated with phytoplankton blooms. Nat Rev Microbiol. 2014;12:686-98. doi:10.1038/nrmicro3326.

5. Callies U, Scharfe M. Mean spring conditions at Helgoland Roads, North Sea: graphical modeling of the influence of hydro-climatic forcing and Elbe River discharge. J Sea Res. 2015;101:1-11. doi:10.1016/j. seares.2014.06.008.

6. Dick S, Kleine E, SH, M-N, Klein H, Komo H. The operational circulation model of BSH (BSHcmod)-model description and validation 2001:29:49.

7. Dormann CF, et al. Collinearity: a review of methods to deal with it and a simulation study evaluating their performance. Ecography. 2013;36:2746. doi:10.1111/j.1600-0587.2012.07348.x.

8. Fortunato C, Crump B. Bacterioplankton community variation across river to ocean environmental gradients. Microb Ecol. 2011;62:374-82. doi:10.1007/s00248-011-9805-z.

9. Fortunato CS, Herfort L, Zuber P, Baptista AM, Crump BC. Spatial variability overwhelms seasonal patterns in bacterioplankton communities across a river to ocean gradient. ISME J. 2012:6:554-63. doi:10.1038/ismej.2011.135.

10. Fuhrman JA, Hewson I, Schwalbach MS, Steele JA, Brown MV, Naeem S. Annually reoccurring bacterial communities are predictable from ocean conditions. Proc Natl Acad Sci USA. 2006;103:13104-9.

11. Fuhrman JA, Steele JA, Hewson I, Schwalbach MS, Brown MV, Green JL, Brown JH. A latitudinal diversity gradient in planktonic marine bacteria. Proc Natl Acad Sci USA. 2008;105:7774-8.

12. Gerdts G, Wichels A, Döpke H, Klings KW, Gunkel W, Schütt C. 40-year long-term study of microbial parameters near Helgoland (German Bight, North Sea): historical view and future perspectives. Helgoland Mar Res. 2004;58:230-42

13. Gilbert J, et al. The seasonal structure of microbial communities in the Western English Channel. Environ Microbiol. 2009;11:3132-9.

14. Gilbert JA et al. Defining seasonal marine microbial community dynamics. ISME J 2012;6:298-308. doi:http://www.nature.com/ismej/journal/v6/ n2/suppinfo/ismej2011107s1.html.

15. Hanson CA, Fuhrman JA, Horner-Devine MC, Martiny JBH. Beyond biogeographic patterns: processes shaping the microbial landscape. Nat Rev Microbiol. 2012;10:497-506.

16. Herlemann DPR, Labrenz M, Jurgens K, Bertilsson S, Waniek JJ, Andersson AF. Transitions in bacterial communities along the $2000 \mathrm{~km}$ salinity gradient of the Baltic Sea. ISME J 2011;5:1571-9 doi:http://www.nature.com/ ismej/journal/v5/n10/suppinfo/ismej201141s1.html.
17. Hewson I, Steele JA, Capone DG, Fuhrman JA. Temporal and spatial scales of variation in bacterioplankton assemblages of oligotrophic surface waters. Mar Ecol Prog Ser. 2006;311:67-77.

18. Hotelling $\mathrm{H}$. The relations of the newer multivariate statistical methods to factor analysis. Br J Stat Psychol. 1957;10:69-79. doi:10.1111/j.2044-8317.1957.tb00179.x.

19. Howarth MJ. North Sea Circulation. In: John HS, editor. Encyclopedia of ocean sciences. Oxford: Academic Press; 2001. p. 1912-21.

20. Kovacs A, Yacoby K, Gophna U. A systematic assessment of automated ribosomal intergenic spacer analysis (ARISA) as a tool for estimating bacterial richness. Res Microbiol. 2010;161:192-7. doi:10.1016/j. resmic.2010.01.006.

21. Krause E, Wichels A, Giménez L, Lunau M, Schilhabel MB, Gerdts G. Small changes in $\mathrm{pH}$ have direct effects on marine bacterial community composition: a microcosm approach. Plos One. 2012;7:e47035. doi:10.1371/ journal.pone.0047035.

22. Lear G, Bellamy J, Case BS, Lee JE, Buckley HL. Fine-scale spatial patterns in bacterial community composition and function within freshwater ponds. ISME J. 2014;8:1715-26. doi:10.1038/ismej.2014.21.

23. Long RA, Azam F. Microscale patchiness of bacterioplankton assemblage richness in seawater. Aquat Microb Ecol. 2001;26:103-13.

24. Lozupone CA, Knight R. Global patterns in bacterial diversity. Proc Natl Acad Sci. 2007;104:11436-40. doi:10.1073/pnas.0611525104.

25. Lübben A, Dellwig O, Koch S, Beck M, Badewien T, Fischer S, Reuter R. Distributions and characteristics of dissolved organic matter in temperate coastal waters (Southern North Sea). Ocean Dyn. 2009;59:263-75. doi:10.1007/s10236-009-0181-x.

26. Lucas J, Koester I, Wichels A, Niggemann J, Dittmar T, Callies U, Wiltshire $\mathrm{KH}$, Gerdts $\mathrm{G}$. Short-term dynamics of North Sea bacterioplanktondissolved organic matter coherence on molecular level. Front Microbiol 2016:7:321. doi:10.3389/fmicb.2016.00321.

27. Lucas J, Wichels A, Teeling H, Chafee M, Scharfe M, Gerdts G. Annual dynamics of North Sea bacterioplankton: seasonal variability superimposes short-term variation. FEMS Microbiol Ecol. 2015. doi:10.1093/ femsec/fiv099.

28. Martiny JBH, Eisen JA, Penn K, Allison SD, Horner-Devine MC. Drivers of bacterial $\beta$-diversity depend on spatial scale. Proc Natl Acad Sci. 2011:108:7850-4. doi:10.1073/pnas.1016308108.

29. Morris RM, Vergin KL, Cho JC, Rappé MS, Carlson CA, Giovannoni SJ. Temporal and spatial response of bacterioplankton lineages to annual convective overturn at the Bermuda Atlantic Time-series Study site. Limnol Oceanogr. 2005;50:1687.

30. Pinhassi J, Sala MM, Havskum H, Peters F, Guadayol Ò, Malits A, Marrasé C. Changes in bacterioplankton composition under different phytoplankton regimens. Appl Environ Microbiol. 2004;70:6753-66. doi:10.1128/ aem.70.11.6753-6766.2004.

31. Raabe T, Wiltshire KH. Quality control and analyses of the long-term nutrient data from Helgoland Roads, North Sea. J Sea Res. 2009;61:3-16. doi:10.1016/j.seares.2008.07.004

32. Ranjard L, Brothier E, Nazaret S. Sequencing bands of ribosomal intergenic spacer analysis fingerprints for characterization and microscale distribution of soil bacterium populations responding to mercury spiking. Appl Environ Microbiol. 2000;66:5334-9. doi:10.1128/ aem.66.12.5334-5339.2000.

33. Rink B, Grüner N, Brinkhoff T, Ziegelmüller K, Simon M. Regional patterns of bacterial community composition and biogeochemical properties in the southern North Sea. Aquat Microb Ecol. 2011;63:207-22. doi:10.3354/ ame01493.

34. Rink B, Seeberger S, Martens T, Duerselen C-D, Simon M, Brinkhoff T. Effects of phytoplankton bloom in a coastal ecosystem on the composition of bacterial communities. Aquat Microb Ecol. 2007;48:47-60. doi:10.3354/ame048047.

35. Rooney-Varga JN, Giewat MW, Savin MC, Sood S, LeGresley M, Martin JL. Links between phytoplankton and bacterial community dynamics in a coastal marine environment. Microb Ecol. 2005;49:163-75.

36. Sapp M, Gerdts G, Wiltshire KH, Wichels A. Bacterial community dynamics during the winter-spring transition in the North Sea. FEMS Microbiol Ecol. 2007:59:622-37.

37. Sarmento $\mathrm{H}$, et al. Phytoplankton species-specific release of dissolved free amino acids and their selective consumption by bacteria. Limnol Oceanogr. 2013;58:1125-35 
38. Scharfe M. Analysis of biological long-term changes based on hydroclimatic parameters in the southern North Sea (Helgoland). University of Hamburg (In German). 2013.

39. Selje N, Simon M. Composition and dynamics of particle-associated and free-living bacterial communities in the Weser estuary, Germany. Aquat Microb Ecol. 2003;30:221-37. doi:10.3354/ame030221.

40. Sogin ML, et al. Microbial diversity in the deep sea and the underexplored "rare biosphere". Proc Natl Acad Sci. 2006;103:12115-20. doi:10.1073/ pnas.0605127103.

41. Sperling M, Giebel HA, Rink B, Grayek S, Staneva J, Stanev E, Simon M. Differential effects of hydrographic and biogeochemical properties on the SAR1 1 clade and Roseobacter RCA cluster in the North Sea. Aquat Microb Ecol. 2012;67:25-34.

42. Staneva J, et al. Hydrodynamics and sediment dynamics in the German Bight. A focus on observations and numerical modelling in the East Frisian Wadden Sea. Cont Shelf Res. 2009;29:302-19. doi:10.1016/j. csr.2008.01.006

43. Stockmann K, Callies U, Manly BFJ, Wiltshire KH. Long-term model simulation of environmental conditions to identify externally forced signals in biological time series. In: Müller F, Baessler C, Schubert H, Klotz S, editors. Long-term ecolocical research: between theory and application. Dordrecht: Springer; 2010. p. 155-62.

44. Störmer R. Benthic bacteria in the German Bight: characterising community structure and influencing environmental factors. Hamburg: University of Hamburg; 2013.
45. Teeling $\mathrm{H}$, et al. Substrate-controlled succession of marine bacterioplankton populations induced by a phytoplankton bloom. Science. 2012;336:608-11. doi:10.1126/science.1218344.

46. Wang K, et al. Bacterial biogeography in the coastal waters of northern Zhejiang, East China Sea is highly controlled by spatially structured environmental gradients. Environ Microbiol. 2015; doi:10.1111/1462-2920.12884.

47. Wemheuer B, Güllert S, Billerbeck S, Giebel H-A, Voget S, Simon M, Daniel R. Impact of a phytoplankton bloom on the diversity of the active bacterial community in the southern North Sea as revealed by metatranscriptomic approaches. FEMS Microbiol Ecol. 2014;87:378-89. doi:10.1111/1574-6941.12230.

48. Whitman WB, Coleman DC, Wiebe WJ. Prokaryotes: the unseen majority. Proc Natl Acad Sci. 1998;95:6578-83.

49. Wiltshire KH, Malzahn AM, Wirtz K, Janisch S, Mangelsdorf P, Manly BFJ. Resilience of North Sea phytoplankton spring bloom dynamics: An analysis of long-term data at Helgoland Roads Limnol Oceanogr. 2008:53:1294-302.

50. Zubkov MV, Fuchs BM, Archer SD, Kiene RP, Amann R, Burkill PH. Linking the composition of bacterioplankton to rapid turnover of dissolved dimethylsulphoniopropionate in an algal bloom in the North Sea. Environ Microbiol. 2001;3:304-11.

\section{Submit your next manuscript to BioMed Central and we will help you at every step:}

- We accept pre-submission inquiries

- Our selector tool helps you to find the most relevant journal

- We provide round the clock customer support

- Convenient online submission

- Thorough peer review

- Inclusion in PubMed and all major indexing services

- Maximum visibility for your research

Submit your manuscript at www.biomedcentral com/submit 